\title{
Lyfjameðferð gláku og hugsanlegar milli- verkanir við meðferð annarra sjúkdóma
}

\author{
Valgerður Dóra Traustadóttir ${ }^{1}$ læknir \\ Elín Björk Tryggvadóttir ${ }^{2}$ læknir \\ Ólöf Birna Ólafsdóttir ${ }^{1,3}$ lífeðlisfræðingur \\ Aðalsteinn Guðmundsson ${ }^{3,4}$ æknir \\ María Soffía Gottfreðsdóttir ${ }^{1,3} \mid æ k n i r$
}

${ }^{4}$ Augndeild Landspítala, ${ }^{2}$ Háskólasjúkrahúsio í Malmö/Lundi, ${ }^{3}$ Háskóla Íslands ${ }^{4}$ öldrunarlækningadeild Landspítala.

Fyrirspurnum svarar Valgerður Dóra Traustadóttir, valadorat@gmail.com

\begin{abstract}
Á G R I P
Inngangur

Gláka er alvarlegur augnsjúkdómur og var algengasti blinduvaldur á íslandi fram á miðja síđustu öld. Par sem tíðni gláku hækkar með aldri eru sjúklingar með gláku oft einnig með ađra sjúkdóma og á margs konar lyfjum. Mikilvægt er að hafa gláku í huga pegar lyfjameðferð pessara sjúklinga er ákveðin par sem augndropameðferð og lyf til inntöku geta haft milliverkanir og aukaverkanir sem skipta sköpum fyrir öryggi og líðan. Markmið rannsóknarinnar var að kanna lyfjameðferð̃ sjúklinga með langt gengna gláku.
\end{abstract}

\section{Aðferðir}

Fram fór afturskyggn rannsókn par sem skoðuð voru gögn 100 einstaklinga sem gengust undir fyrstu hjáveituaðgerð við gláku á Landspítala árin 2013-2017. Skráo voru lyf til inntöku á 6 mánaða tímabili fyrir og eftir aðgerð, glákumeðferð fyrir aðgerð, helstu sjúkdómsgreiningar ásamt aldri og kyni.

\section{Niðurstöður}

Meðalaldur við aðgerð var 75 ár og voru 53 konur í hópnum. Af 100 sjúklingum voru 87 á lyfjum við öðrum sjúkdómum og meðalfjöldi lyfja til inntöku var 5,3 lyf á mann. Međalfjöldi augnprýstingslækkandi lyfja var 3,0 á mann. Prostaglandín-hliðstæður voru algengasta augnprýstingslækkandi lyfið. Algengasti lyfjaflokkurinn vegna annarra sjúkdóma var blóðprýstingslækkandi lyf sem 57 sjúklingar tóku að staðaldri, par af voru 30 sjúklingar á beta-blokkum. Zópíklón var algengasta einstaka lyfið, 29 sjúklingar tóku pað.

\section{Ályktun}

Sjúklingar með gláku taka ýmis lyf vegna annarra sjúkdóma sem geta haft áhrif á glákuna og milliverkanir við glákulyf. Pegar lyfjameðferð er ákveðin fyrir einstakling með gláku parf að hafa í huga hugsanlegar milliverkanir annarra lyfja við gláku og hins vegar milliverkanir glákulyfja við ađra sjúkdóma.

https://doi.org/10.17992/lbl.2019.04.225

stigi og parfnast hjáveituaðgerðar (trabeculectomy), einnig að setja meðferð glákusjúklinga í samhengi við aukaverkanir glákulyfja og hugsanlegar milliverkanir lyfja til inntöku við glákusjúkdóminn.

gleiðhornsgláka er að miklu leyti sjúkdómur fólks og meðferð glákusjúklinga getur pví oft verið flókin par sem sjúklingarnir nota mörg lyf, bæði augnlyf og lyf við öðrum sjúkdómum. Augnlæknar eru pví ekki einungis ábyrgir fyrir pví að meðhöndla augnsjúkdóminn, lækka augnprýsting og koma í veg fyrir blindu, heldur verða peir einnig að taka tillit til hugsanlegra áhrifa lyfja til inntöku á glákusjúkdóminn. Einnig er mikilvægt að læknar séu meðvitaðir um hugsanlegar milliverkanir augnprýstingslækkandi meðferðar á aðra sjúkdóma.

Tilgangur pessarar rannsóknar var að skoða heildarlyfjameðferð íslenskra glákusjúklinga sem eru með sjúkdóm á alvarlegu

\section{Aðferðir}

Leyfi voru fengin fyrir rannsókninni hjá siðanefnd heilbrigðisvísinda á Landspítala og framkvæmdastjóra lækninga.

Rannsóknin var afturskyggn. Sjúklingar voru fundnir með leit að ICD-10 númeri hjáveituaðgerða í augum (CHSD15) í gagnagrunni Landspítala. Leitað var aftur í tímann að samtals 100 einstaklingum sem gengust undir hjáveituaðgerð við gleiðhorns- 
Tafla I. Fjöldi einstaklinga á tiltekinni augnprýstingslækkandi meðferð.

\begin{tabular}{lc}
\hline Augnprýstingslækkandi meðferð & Fjöldi \\
\hline Prostaglandín-hliðstæður & 92 \\
\hline Beta-blokkar & 80 \\
\hline Karbóanhýdrasa-hemlar & 71 \\
\hline Adrenvirk lyf & 40 \\
\hline Karbóanhýdrasa-hemlar um munn & 11 \\
\hline Pílókarpín & 10 \\
\hline
\end{tabular}

gláku á Landspítala, pannig náði rannsóknartímabilið frá hluta árs 2017 til hluta árs 2013. Útilokaðir voru peir sem höfðu áður gengist undir skurðaðgerð við gláku. Hver einstaklingur kom aðeins einu sinni fyrir í rannsókninni pó svo að aðgerð hafi verið framkvæmd á báðum augum. Athuguð voru gögn í sjúkraskrám einstaklinga í Sögukerfinu og í sjúkraskrám augnlækna. Einnig var stuðst við lyfjagagnagrunn landlæknis við öflun upplýsinga. Skráðar voru sjúkdómsgreiningar einstaklinga ásamt aldri og kyni. Skráð voru öll lyf til inntöku á 6 mánaða tímabili, bæði fyrir og eftir aðgerð. Lausasölulyf voru ekki talin með nema peirra væri sérstaklega getið í sjúkraskrá eða lyfseðill leystur út í lyfjagagnagrunni landlæknis. Lyf til innöndunar, útvortis notkunar og lyf til innspýtingar voru ekki talin með í rannsókninni. Vítamín og bætiefni voru ekki tekin með. Skráð var augnprýstingslækkandi meðferð fyrir aðgerð, en pær upplýsingar voru aðgengilegar í sjúkraskrám augnlækna um allt rannsóknarpýðið. Stuðst var við ATC-flokkun við skráningu á lyfjum.

\section{Niðurstödur}

Rannsóknin náði til 100 einstaklinga. Konur voru 53 og karlar 47. Aldur sjúklinga var 45 til 94 ára og var meðalaldur peirra $75 \pm 11$ ár, miðgildi aldurs var 78 ár. Meðalfjöldi lyfja, annarra en glákulyfja var 5,3 lyf á peim tíma sem aðgerðin fór fram. Prettán einstaklingar tóku engin lyf önnur en glákulyf, en hjá peim 87 einstaklingum sem tóku lyf, var lyfjanotkun 6,1 lyf að meðaltali, allt frá einu lyfi upp í 18 lyf.

\section{Glákulyf}

Meðalfjöldi augnprýstingslækkandi lyfja var 3,0 lyf á hvern sjúkling. Prostaglandín-hliðstæður voru algengasta augnprýstingslækkandi lyfið, notað af 92 sjúklingum. Næstalgengastir voru beta-blokkar hjá 80 sjúklingum, par næst karbóanhýdrasa-hemlar í dropaformi sem 71 sjúklingur notaði. Yfirlit yfir augnprýstingslækkandi meðferð rannsóknarpýðisins er í töflu I.

\section{Sjúkdómsgreiningar og lyf til inntöku}

Algengasti lyfjaflokkurinn var blóðprýstingslækkandi lyf sem 57 sjúklingar notuðu. Næstalgengasti lyfjaflokkurinn voru svefnlyf og kvíðastillandi lyf sem 40 sjúklingar notuðu. Á pvagræsilyfjum voru 36 og 32 á blóðpynnandi meðferð. Í töflu II má sjá 15 algengustu lyfjaflokkana sem hópurinn notaði. Algengasta einstaka lyfið
Tafla II. Fjöldi einstaklinga á tiltekinni meðferð.

\begin{tabular}{ll}
\hline Lyfjaflokkur & Fjöldi \\
\hline Blóðprýstingslækkandi lyf & 57 \\
\hline Svefn- og kvíðastillandi lyf & 40 \\
\hline Pvagræsilyf & 36 \\
\hline Segavarnarlyf og lyf sem hindra & 32 \\
samloðun blóðflagna & \\
\hline Prótónpumpuhemlar & 31 \\
\hline Önnur verkjalyf og hitalækkandi lyf \\
(parasetamól) & 30 \\
\hline Blóðfitulækkandi lyf & 29 \\
\hline Kódein og sterk verkjalyf & 24 \\
\hline Punglyndislyf & 22 \\
\hline Bólgueyðandi lyf og gigtarlyf & 17 \\
\hline Kynhormónar & 13 \\
\hline Skjaldkirtilshormónar & 12 \\
\hline Astmalyf & 11 \\
\hline Sykursterar & 11 \\
\hline Pvagfæralyf (sildenafil) & 8 \\
\hline &
\end{tabular}

var svefnlyfið zópíklón sem var notað af 29 sjúklingum. Í töflu III má sjá undirflokka fjögurra algengustu lyfjaflokkanna.

Meðalfjöldi sjúkdómsgreininga sem pörfnuðust lyfjameðferðar var 2,8 greiningar á hvern einstakling og má sjá yfirlit yfir helstu greiningar í töflu IV. Hafa verður í huga að upplýsingar um sjúkdómsgreiningar voru ekki alltaf aðgengilegar og pví eru pær niðurstöður aðeins til viðmiðunar.

\section{Umræða}

Lyfjanotkun og augndropameðferð

Til samanburðar við rannsókn Maríu Gottfreðsdóttur og félaga, ${ }^{5}$ sem var framkvæmd í Bandaríkjunum, er lyfjanotkun íslenska pýðisins mun meiri en pess bandaríska. Par var notkunin aðeins 3,5 samanborið við 5,3 lyf að meðaltali hér á landi. Hins vegar verður að hafa í huga að meðalaldur pýðisins í pessari rannsókn er um pað bil 10 árum hærri og er með svo langt gengna gláku að skurðaðgerðar er pörf. Einnig er samsetning hópsins önnur og einsleitari á Íslandi. Frá peim tíma sem María Gottfreðsdóttir gerði sína rannsókn 1997 hefur orðið mikil aukning á fjöllyfjameðferð um allan heim. ${ }^{6}$

Í grein í Læknablaðinu frá 2013 er lyfjanotkun einstaklinga á hjúkrunarheimilum á Íslandi skoðuð árin 2002-2004 og er meðalfjöldi lyfja 10 á hvern einstakling. ${ }^{7}$ Hins vegar er meðalaldurinn í peirri rannsókn 8 árum hærri en í okkar pýði en 13\% voru á glákumeðferð. Pó verður að setja pann fyrirvara við niðurstöður að lausasölulyf, innöndunarlyf og lyf til innspýtingar voru ekki talin með í rannsókninni og er meðalfjöldi lyfja líklega vanáætlaður af pessum sökum.

Erfitt getur verið fyrir eldra fólk að halda utan um augndropameðferð og sérstaklega pegar pað notar einnig fjölda annarra 
Tafla III. Undirflokkar algengustu lyfja.

\begin{tabular}{|c|c|}
\hline Blóðprýstingslyf & Fjöldi \\
\hline Beta-blokkar & 30 \\
\hline Angiótensín II-viðtakahemlar (ARB) & 27 \\
\hline $\mathrm{Ca}++$ gangalokar & 20 \\
\hline Díhýdrópyridín & 19 \\
\hline Ekki-díhýdrópyridín & 1 \\
\hline Angíótensín-breytihvatahemlar (ACE) & 9 \\
\hline Pvagræsilyf & Fjöldi \\
\hline Píazíð & 23 \\
\hline Fúrosemíð & 13 \\
\hline Amilorid & 9 \\
\hline Spírónalaktón & 2 \\
\hline Blóðpynning & Fjöldi \\
\hline Asetýlsalisýlsýra & 20 \\
\hline Warfarín & 9 \\
\hline Klópídrógel & 3 \\
\hline Xa-hemill & 3 \\
\hline Enoxaparín & 1 \\
\hline Svefn- og kvíðastillandi lyf & Fjöldi \\
\hline Zópíklón & 29 \\
\hline Oxasepam & 10 \\
\hline Alprazolam & 4 \\
\hline Zolpidemtartrat & 3 \\
\hline Flunitrazepam & 1 \\
\hline Brómazepam & 1 \\
\hline Díazepam & 1 \\
\hline
\end{tabular}

lyfja. Meðferðarheldni ræðst af mörgum páttum, svo sem fjölda lyfja, aukaverkunum og kostnaði, en einnig af pví að gláka getur verið einkennalaus. ${ }^{8,9}$ Hafa verður í huga að fjöllyfjameðferð, sjúkdómsbyrði einstaklings og færniskerðing getur gert sjúklingum erfitt fyrir að koma dropanum í augað, sérstaklega par sem margir hverjir hafa misst sjónina til að leysa pað verkefni af hendi með góðum árangri. ${ }^{8,9}$ Mikilvægt er að ræða pessi atriði við einstaklinga sem nota augndropa að staðaldri og meta hvort pörf sé á ráðgjöf og aðstoð.

Mikilvægt er að heilbrigðisstarfsfólk hafi í huga að augndropar eru lyf sem geta haft margvíslegar líkamlegar aukaverkanir prátt fyrir að lyfin séu aðeins gefin staðbundið í augu. Lyf í augndropaformi frásogast í táru, slímhúð í táragöngum og nefi og ná pannig dreifingu í blóði og geta aukaverkanir verið svipaðar eins og lyfið sé gefið um munn. ${ }^{10}$ Mikilvægt er að fylgja leiðbeiningum framleiðanda pegar sjúklingum er kennt að nota augndropa til pess að minnka frásog lyfsins og dreifingu pess í blóðrás. Rannsóknir hafa sýnt að með pví að prýsta fingri hjá nefrót til pess að loka táragangi og hafa augun lokuð í nokkrar mínútur eftir að augndropi er gefinn, fæst hámarksvirkni lyfs í auga og frásog minnkar. ${ }^{11,12}$ Sannreynt hefur verið að styrkur lyfs í blóði getur minnkað um 40-60\% ef lokað er fyrir táragöng með pessum hætti
Tafla IV. Helstu sjúkdómsgreiningar pýđisins.

\begin{tabular}{ll}
\hline Sjúkdómur & Fjöldi \\
\hline Hár blóðprýstingur & 62 \\
\hline Háar blóðfitur & 31 \\
\hline Maga- og bakflæðissjúkdómur & 28 \\
\hline Kransæðasjúkdómur & 22 \\
\hline Kvíði og punglyndi & 22 \\
\hline Gigt & 21 \\
\hline Vanvirkur skjaldkirtill & 12 \\
\hline Gáttatif & 11 \\
\hline Astmi og langvinn lungnateppa & 11 \\
\hline Heilablóðfall & 9 \\
\hline Blöðruhálskirtilsstækkun & 8 \\
\hline Sykursýki & 6 \\
\hline
\end{tabular}

ásamt pví að hafa augu lokuð. ${ }^{13,14}$ Í töflu V má sjá helstu aukaverkanir glákulyfja.

Áhrif meðferðar annarra sjúkdóma á gláku

Yfir helmingur sjúklinga í rannsókninni notaði blóðprýstingslækkandi lyf. Petta er í samræmi við aðrar rannsóknir sem hafa sýnt samband á milli hækkaðs blóðprýstings og gláku. ${ }^{15}$ Talið er að blóðprýstingslækkandi lyf geti minnkað blóðflæði til sjóntaugar (reduced perfusion pressure) og pannig ýtt undir skemmdir á sjóntaug peirra sem eru með gláku. ${ }^{16}$ Pað er pví mikilvægt að fylgjast vel með sjón og einkennum glákusjúklinga pegar blóðprýstingsmeðferð er hafin. Pessi lyf geta haft fjölpættar milliverkanir við glákulyf, sjá í töflu VI.

Fjölmörg lyf geta ýtt undir prönghornsgláku. ${ }^{17}$ Peirra á meðal eru andkólínvirk og adrenvirk lyf. Andkólínvirk lyfhrif eru pekkt aukaverkun margra lyfja og hjá öldruðum sem taka ýmis lyf getur samanlögð andkólínvirkni aukið pessa hættu enn frekar. ${ }^{18}$ Andkólínvirk lyf geta pannig valdið hækkuðum prýstingi í auga með pví að slaka á brárvöðva (ciliary muscle) pannig að lithimna og

Tafla V. Helstu aukaverkanir augnprýstingslækkandi meðferðar.

\begin{tabular}{l|l}
\hline $\begin{array}{l}\text { Augnprýstingslækkandi } \\
\text { meðferð }\end{array}$ & \multicolumn{1}{c}{ Helstu aukaverkanir } \\
\hline Prostaglandín-hliðstæður & $\begin{array}{l}\text { Roði í táru (conjunctivu), litabreyting á lithimnu } \\
\text { (iris), ofvöxtur á augnhárum²0 }\end{array}$ \\
\hline Beta-blokkar & $\begin{array}{l}\text { Lágprýstingur, hægur hjartsláttur, prenging í } \\
\text { berkju, versnun á astma }{ }^{41}\end{array}$ \\
\hline Karbóanhýdrasa-hemlar & Höfuðverkur, ógleði og beiskt bragð ${ }^{42}$ \\
\hline Adrenvirk lyf & Höfuðverkur, preyta, purrkur í munni og nefi ${ }^{43}$ \\
\hline Karbóanhýdrasa-hemlar & $\begin{array}{l}\text { Blóðsýring, náladofi, svimi, preyta og vanlíðan, } \\
\text { bragðtruflanir, beinmergsbæling, nýrnasteinar }\end{array}$ \\
\hline um munn & $\begin{array}{l}\text { Höfuðverkur, svimi, ógleði, versnun á astma, } \\
\text { pokusýn }{ }^{39}\end{array}$ \\
\hline
\end{tabular}


Tafla VI. Helstu milliverkanir augnprýstingslækkandi meðferðar og lyfja til inntöku.

\begin{tabular}{|c|c|c|c|c|c|}
\hline Lyfjaflokkur & $\begin{array}{l}\text { Prostaglandín- } \\
\text { hliðstæður }\end{array}$ & Beta-blokkar & $\begin{array}{l}\text { Karbóanhýdrasa- } \\
\text { hemlar - um munn }\end{array}$ & Adrenvirk lyf & Pílókarpín \\
\hline Beta-blokkar & $\begin{array}{l}\text { Ekki pekktar } \\
\text { milliverkanir. }\end{array}$ & $\begin{array}{l}\text { Aukin hæging á } \\
\text { hjartslætti versnun } \\
\text { astma og lungnateppu, } \\
\text { blóðfituröskun, lækkað } \\
\text { geðslag, getuleysi. }\end{array}$ & $\begin{array}{l}\text { Erfiðleikar við svefn og } \\
\text { lækkað geðslag. }\end{array}$ & Hæging hjartsláttar. & $\begin{array}{l}\text { Getur aukið prengingu } \\
\text { í berkju hjá sjúklingum } \\
\text { með astma. Aukin } \\
\text { lækkun blóðprýstings. }\end{array}$ \\
\hline ACE-hemlar og ARB & $\begin{array}{l}\text { Ekki pekktar } \\
\text { milliverkanir. }\end{array}$ & $\begin{array}{l}\text { Aukin hætta á lágum } \\
\text { blóðprýstingi. }\end{array}$ & Beinmergsbæling. & $\begin{array}{l}\text { Blóðprýstingslækkandi } \\
\text { áhrif geta minnkað. }\end{array}$ & $\begin{array}{l}\text { Bæði lyf geta valdið } \\
\text { höfuðverk. Aukin } \\
\text { æðavíkkandi áhrif og } \\
\text { lækkun blóðprýstings. }\end{array}$ \\
\hline $\mathrm{Ca}++$ gangalokar & $\begin{array}{l}\text { Ekki pekktar } \\
\text { milliverkanir. }\end{array}$ & $\begin{array}{l}\text { Bæði lyfin hafa bælandi } \\
\text { áhrif á hjarta, hægur } \\
\text { hjartsláttur, lágur } \\
\text { blóðprýstingur. }\end{array}$ & $\begin{array}{l}\text { Aukin hætta á dofatilfinningu } \\
\text { og vanlíðan. }\end{array}$ & $\begin{array}{l}\text { Aukin hætta á ógleði, } \\
\text { uppköstum og } \\
\text { kviðarholsópægindum. }\end{array}$ & $\begin{array}{c}\text { Bæði lyf geta valdið } \\
\text { höfuðverk, ógleði og } \\
\text { aukið æðavíkkandi áhrif. }\end{array}$ \\
\hline Pvagræsilyf - píasíð & $\begin{array}{l}\text { Ekki pekktar } \\
\text { milliverkanir. }\end{array}$ & $\begin{array}{l}\text { Aukin hætta á lágum } \\
\text { blóðprýstingi. Hækkun á } \\
\text { blóðfitum og blóðsykri. }\end{array}$ & $\begin{array}{l}\text { Aukin hætta á lágu kalíum- } \\
\text { gildi í blóđi, aukin pvagsýra í } \\
\text { blóđi og beinmergsbæling. }\end{array}$ & $\begin{array}{l}\text { Hjartsláttartruflanir. Bæði } \\
\text { lyf geta valdið höfuðverk. }\end{array}$ & $\begin{array}{l}\text { Bæði lyf geta valdið } \\
\text { höfuðverk. }\end{array}$ \\
\hline Asetýlsalisýlsýra & $\begin{array}{l}\text { Ekki pekktar } \\
\text { milliverkanir. }\end{array}$ & $\begin{array}{l}\text { Getur komið í veg fyrir } \\
\text { augnprýstingslækkandi } \\
\text { áhrif. }\end{array}$ & $\begin{array}{l}\text { Gæti aukið metabolíska } \\
\text { súrnun og lækkað kalíum- } \\
\text { gildi í blóði. Hætta á } \\
\text { miðtaugakerfiseitrun vegna } \\
\text { hækkunar á klór í blóði. }\end{array}$ & $\begin{array}{l}\text { Getur minnkað } \\
\text { augnprýstings- } \\
\text { lækkandi virkni. }\end{array}$ & $\begin{array}{l}\text { Bæði lyf geta valdið } \\
\text { ógleði ef notuð í stórum } \\
\text { skömmtum. }\end{array}$ \\
\hline Verkjalyf - NSAID & $\begin{array}{c}\text { Notkun NSAIDs } \\
\text { gæti minnkað } \\
\text { augnprýstilækkandi } \\
\text { virkni. }\end{array}$ & $\begin{array}{c}\text { Getur hamlað } \\
\text { augnprýstingslækkandi } \\
\text { virkni. }\end{array}$ & $\begin{array}{l}\text { Geta minnkað áhrif } \\
\text { karbóanhýdrasa-hemla. } \\
\text { Bæði lyf geta valdið } \\
\text { beinmergsbælingu. }\end{array}$ & $\begin{array}{l}\text { Geta hækkað } \\
\text { blóðprýsting. NSAIDs } \\
\text { geta minnkað } \\
\text { augnprýstings- } \\
\text { lækkandi virkni. }\end{array}$ & $\begin{array}{l}\text { Bæði lyf geta valdið } \\
\text { ógleði og uppköstum. }\end{array}$ \\
\hline $\begin{array}{l}\text { Punglyndislyf + } \\
\text { MAO-blokkar }\end{array}$ & $\begin{array}{l}\text { Ekki pekktar } \\
\text { milliverkanir. }\end{array}$ & $\begin{array}{l}\text { Sum SSRI-lyf geta aukið } \\
\text { virkni beta-blokkara með } \\
\text { hömlun á niðurbroti. }\end{array}$ & Ekki pekktar milliverkanir. & $\begin{array}{c}\text { Getur valdið alvarlegum } \\
\text { háprýstingi ef tekið með } \\
\text { MAO-blokkara. }\end{array}$ & $\begin{array}{l}\text { Ekki pekktar } \\
\text { milliverkanir. }\end{array}$ \\
\hline Sykursýkislyf & $\begin{array}{l}\text { Ekki pekktar } \\
\text { milliverkanir. }\end{array}$ & $\begin{array}{l}\text { Beta-blokkar geta falið } \\
\text { einkenni lágs blóðsykurs. }\end{array}$ & $\begin{array}{l}\text { Lágt kalíumgildi í blóði vegna } \\
\text { karbóanhýdrasa-hemla getur } \\
\text { raskað blóðsykurjafnvægi. }\end{array}$ & $\begin{array}{l}\text { Áhrif insúlíns geta } \\
\text { minnkað vegna } \\
\text { alfa-agonista }\end{array}$ & $\begin{array}{l}\text { Bæði lyf geta valdið } \\
\text { ógleði og uppköstum }\end{array}$ \\
\hline Skjaldkirtilshormón & $\begin{array}{l}\text { Ekki pekktar } \\
\text { milliverkanir. }\end{array}$ & $\begin{array}{c}\text { Augnprýstings- } \\
\text { lækkandi virkni getur } \\
\text { minnkað pegar } \\
\text { skjaldkirtilshormón í blóði } \\
\text { er leiðrétt úr lágu í eðlilegt } \\
\text { gildi. }\end{array}$ & $\begin{array}{l}\text { Karbóanhýdrasar-hemlar } \\
\text { geta haft áhrif á upptöku } \\
\text { joðs í skjaldkirtli. }\end{array}$ & $\begin{array}{l}\text { Thyroxín getur aukið } \\
\text { virkni alfa-agonista. }\end{array}$ & $\begin{array}{c}\text { Bæði lyf geta } \\
\text { valdið niðurgangi, } \\
\text { vöðvaslappleika og } \\
\text { skjálfta }\end{array}$ \\
\hline Svefn og slævandi lyf & $\begin{array}{l}\text { Ekki pekktar } \\
\text { milliverkanir. }\end{array}$ & $\begin{array}{l}\text { Dífenhýdramín getur } \\
\text { hindrað niðurbrot timolóls. }\end{array}$ & Ekki pekktar milliverkanir. & $\begin{array}{l}\text { Aukin bæling } \\
\text { miðtaugakerfis ef tekið } \\
\text { með benzodíazepíni. }\end{array}$ & $\begin{array}{l}\text { Ekki pekktar } \\
\text { milliverkanir. }\end{array}$ \\
\hline Hjartaglýkósíd & $\begin{array}{l}\text { Ekki pekktar } \\
\text { milliverkanir. }\end{array}$ & $\begin{array}{l}\text { Hægur hjartsláttur, aukin } \\
\text { hætta á AV-leiðnitruflunum. }\end{array}$ & $\begin{array}{l}\text { Sjúklingar með lágt } \\
\text { kalíumgildi í blóði vegna } \\
\text { karbóanhýdrasa-hemla } \\
\text { eru í meiri hættu á } \\
\text { að fá eitrunaráhrif frá } \\
\text { hjartaglýkósíðum. }\end{array}$ & $\begin{array}{l}\text { Aukin æðaherpandi áhrif } \\
\text { og hjartsláttartruflanir. }\end{array}$ & $\begin{array}{l}\text { Bæði lyf geta valdið } \\
\text { höfuðverk og ógleði. } \\
\text { Hæging hjartsláttar í } \\
\text { stórum skömmtum. }\end{array}$ \\
\hline Prótónpumpuhemlar & \multicolumn{5}{|c|}{ Ekki pekktar milliverkanir við glákulyf. } \\
\hline Blóðfitulækkandi lyf & \multicolumn{5}{|c|}{ Ekki pekktar milliverkanir við glákulyf. Hugsanleg jákvæð áhrif á augnprýsting. Aukið rennsli augnvökva um síukerfi. } \\
\hline $\begin{array}{l}\text { Frábendingar } \\
\text { augnlyfja }\end{array}$ & $\begin{array}{l}\text { Prönghornsgláka, } \\
\text { augnsýking og } \\
\text { bólga. }\end{array}$ & $\begin{array}{c}\text { Astmi, langvinn } \\
\text { lungnateppa, hjartabilun } \\
\text { með einkennum, sínus } \\
\text { hægtaktur, } 2^{\circ} \text { og } 3^{\circ} \mathrm{AV} \\
\text { blokk. }\end{array}$ & Ofnæmi fyrir súlfalyfjum. & $\begin{array}{l}\text { Alvarlegur hár } \\
\text { blóðprýstingur. }\end{array}$ & $\begin{array}{l}\text { Slæmur astmi, bráð } \\
\text { lithimnubólga. }\end{array}$ \\
\hline
\end{tabular}


augasteinn færast framar og hornið milli lithimnu og hornhimnu prengist og vökvi kemst ekki að síukerfi augans. ${ }^{17}$

Sykursterar og sum krabbameinslyf eru talin geta valdið gleiðhornsgláku. ${ }^{19}$ Pví er mikilvægt að fylgjast vel með augnprýstingi hjá sjúklingum sem hafa áđur greinst með gláku eða par sem gláka er í ættinni ef peir eru settir á sykurstera.

\section{Milliverkanir}

Prostaglandín-hliðstæður

Prostaglandín-hliðstæður voru mest notaða glákulyfið í rannsókninni, hjá 92 einstaklingum, enda er pað öflugt lyf og polist vel. ${ }^{20}$ Lítið er um alvarlegar aukaverkanir og milliverkanir við lyf til inntöku. ${ }^{21}$ Hins vegar er pekkt að notkun prostaglandín-hliðstæðna í auga getur aukið hættu á bjúgmyndun í augnbotni, sér í lagi hjá peim sem hafa farið í augasteinaskipti eða gengist undir aðrar augnaðgerðir. ${ }^{22}$

\section{Beta-blokkar í augndropaformi}

Timolól er ósértækur beta-blokki og öflugt glákulyf ${ }^{23}$ en $80 \%$ rannsóknarpýðisins notaði petta lyf. Beta-blokkar í augndropaformi geta valdið sömu aukaverkunum og beta-blokkar sem teknir eru um munn. ${ }^{24,25}$ Mælt er með að fara varlega við notkun peirra hjá sjúklingum sem eru með astma, langvinna lungnateppu, leiðslutruflanir í hjarta á borð við sjúkan sínushnút, sínushægslátt, leiðslurof í gáttum ásamt einkennavaldandi hjartabilun. ${ }^{23}$ Betablokkar geta einnig valdið röskun á blóðfitum og lækkað styrk HDL-kólesteróls í blóði ${ }^{26}$ en 29 einstaklingar í sjúklingapýðinu notuðu blóðfitulækkandi lyf. Einnig er pekkt að beta-blokkar í augndropaformi geta dulið einkenni blóðsykursfalls hjá sykursjúkum. ${ }^{27}$ Athygli vekur að í okkar rannsókn voru aðeins fjórir sjúklinganna með sykursýki, samanborið við 17 sjúklinga í rannsókn Maríu Gottfreðsdóttur. ${ }^{5}$ Petta má hugsanlega skýra með ólíkum lífsháttum í Bandaríkjunum miðað við á Íslandi og einnig par sem hlutfall fólks af afrískum uppruna var um 20\% í rannsókn Maríu Gottfreðsdóttur en sykursýki er algengari hjá peim hópi. ${ }^{28}$

Eins og fram kemur að ofan frásogast lyf í augndropum í gegnum slímhúð táragangs og nefs. ${ }^{11}$ Pannig fer timolól fram hjá fyrsta stigs umbroti í lifur og dreifist um líkamann. Rannsókn Korte og félaga sýndi að styrkur timolóls í blóði eftir gjöf í augndropaformi er svipaður og ef lyfið væri gefið í æð.. ${ }^{29}$ Pví meiri sem styrkur timolóls er í blóði pví meiri eru altæk áhrif pess á líkamann ${ }^{30}$ og um leið aukast líkur á aukaverkunum. Timolól er brotið niður af CYP2D6 ${ }^{31}$ (Cytochrome P 450 2D6) og getur styrkur pess í blóði aukist marktækt ef lyfið er gefið peim sem fyrir eru að taka CYP2D6-hemla á borð við punglyndislyfið paroxetín ${ }^{32}$ og hjartsláttaróreglulyfið quinidín. ${ }^{31}$ Í rannsókninni voru 22 einstaklingar á punglyndislyfjum en pekkt er að notkun SSRI-lyfja er algeng í pessum aldurshópi á Íslandi. ${ }^{33}$

Ef timolól-augndropar eru notaðir samhliða kalsíumgangalokanum verapamíl getur komið fram alvarleg hæging á hjartslætti. ${ }^{34}$
Í rannsókninni voru 20 sjúklingar á kalsíumgangalokum. Einnig geta komið fram samlegðaráhrif á lækkun blóðprýstings og hjartsláttarhægingu ef timolól er notað samhliða öðrum beta-blokkum til inntöku. ${ }^{35}$

\section{Karbóanhýdrasa-hemlar}

Karbóanhýdrasa-hemlar eru mikið notaðir meðal glákusjúklinga í augndropaformi en einnig töflum um munn. Helstu aukaverkanir og milliverkanir koma fram pegar lyfið er tekið um munn en styrkur lyfsins í blóði eftir augndropagjöf er hverfandi ${ }^{36}$ og pví litlar líkur á alvarlegum aukaverkunum. ${ }^{37}$ Hins vegar getur asetasólamíð um munn haft milliverkanir við fjölmörg lyf á borð við pvagræsilyf, asetýlsalisýlsýru, digoxín, sykursýkislyf, litíum og sýklósporín. ${ }^{8}$ Asetasólamíð getur valdið metabólískri súrnun (metabolic acidosis) með auknum útskilnaði bíkarbónats í pvagi og lækkuðu gildi kalíums og natríums í blóði, sérstaklega ef pað er tekið samhliða píasíð-pvagræsilyfjum, sem 23 sjúklingar í rannsókninni voru á. Einnig er aukin hætta á nýrnasteinum og beinmergsbælingu. ${ }^{35}$ Asetýlsalisýlsýra minnkar próteinbindingu asetasólamíðs í blóðvökva og getur pví valdið aukinni metabólískri súrnun og lækkað kalíumgildi í blóði enn frekar. ${ }^{38}$ Í rannsókninni tóku að minnsta kosti 20 einstaklingar asetýlsalisýlsýru að staðaldri, en pessi tala gæti verið hærri par sem lyfið er selt í lausasölu.

\section{Adrenvirk lyf}

Adrenvirk lyf í augndropaformi eru einnig algeng glákulyf en tæplega helmingur einstaklinga í rannsókninni notaði pessi lyf. pekkt er að notkun adrenvirkra lyfja samhliða príhringlaga punglyndislyfjum eða mónóamíðoxídasa (MAO) hemlum getur hækkað blóðprýsting verulega. ${ }^{8,35}$ Раð er pví ekki mælt með notkun pessara lyfja saman.

\section{Pílokarpín}

Pílokarpín er eitt elsta lyfið við gláku og hefur verið notað síðan á 18. öld. •að er mikilvæg viðbót við nútímameðferð og virkar pannig að sjáaldrið dregst saman og á vökvi greiðari leið að síukerfi augans. ${ }^{39}$ Pílokarpín getur verið varhugavert fyrir sjúklinga sem hafa greinst með geðrof eða geðrofseinkenni. ${ }^{40}$

\section{Lokaorð}

Glákusjúklingar eru viðkvæmur sjúklingahópur og eru oft með aðra langvinna sjúkdóma og taka fjölda annarra lyfja. Mikilvægt er að bæði læknar og annað heilbrigðisstarfsólk, sem hefur pennan hóp sjúklinga í sinni umsjá, hafi í huga að glákulyf í augndropaformi geta haft ýmsar aukaverkanir og milliverkandi áhrif á aðra sjúkdóma. Einnig er mikilvægt að leiðbeina sjúklingum um rétta meðferð við gjöf augndropa til að minnka upptöku lyfs í blóðrás. 


\section{Heimildir}

1. Bjornsson G. Prevalence and causes of blindness in Iceland, with special reference to glaucoma simplex. Am J Ophthalmol 1955; 39: 202-8.

2. Gunnlaugsdottir E, Arnarsson A, Jonasson F. Prevalence and causes of visual impairment and blindness in Icelanders aged 50 years and older: The Reykjavik Eye Study. Acta Ophthalmolog 2008 ; 86:778-85.

3. Jonasson F, Damii KF, Arnarsson A, Sverrisson T, Wang L, Sasaki H, et al. Prevalence of open-angle glaucoma in Iceland: The Reykjavik Eye Study. Eye (London, England) 2003; 17: 747-53.

4. Weinreb RN, Aung T, Medeiros FA. The pathophysiology and treatment of glaucoma: a review. JAMA 2014; 311: 1901-11.

5. Gottfredsdottir MS, Allingham RR, Shields MB Physicians' ${ }^{\prime}$ guide to interactions between glaucoma and systemic medications. J Glaucoma 1997; 6: 377-83.

6. Hovstadius B, Hovstadius K, Astrand B, Petersson G Increasing polypharmacy - an individual-based study of the Swedish population 2005-2008. BMC Clin Pharmacol 2010; 10: 16

7. Hansdóttir H, Guðmannsson PG. Lyfjanotkun á hjúkrunarheimilum á Íslandi 2002-2004. Lýsandi rannsókn. Læknablaðið 2013; 99: 383-9.

8. Broadway DC, Cate H. Pharmacotherapy and adherence issues in treating elderly patients with glaucoma. Drugs Aging 2015; 32: 569-81.

9. Sleath B, Robin AL, Covert D, Byrd JE, Tudor G, Svarstad B. Patient-reported behavior and problems in using glaucoma medications. Ophthalmol 2006; 113: 431-6.

10. Novack GD, Robin AL. Ocular pharmacology. J Clin Pharmacol 2016; 56: 517-27.

11. Flach AJ. The importance of eyelid closure and nasolacrimal occlusion following the ocular instillation of topical glaucoma medications, and the need for the universal inclusion of one of these techniques in all patient treatments and clinical studies. Transa Am Ophthalmol Soc 2008; 106: 138-48

12. Fraunfelder FT. Extraocular fluid dynamics: how best to apply topical ocular medication. Transa Am Ophthalmol Soc 1976; 74: 457-87.

13. Passo MS, Palmer EA, Van Buskirk EM. Plasma timolol in glaucoma patients. Ophthalmol 1984; 91: 1361-3.

14. Zimmerman TJ, Kooner KS, Kandarakis AS, Ziegler LP. Improving the therapeutic index of topically applied ocular drugs. Arch Ophthalmol 1984; 102: 551-3.

15. Chung HJ, Hwang HB, Lee NY. The association between primary open-angle glaucoma and blood pressure: two aspects of hypertension and hypotension. BioMed Res Int 2015; 2015: 827516
16. Bonomi L, Marchini G, Marraffa M, Bernardi P, Morbio $\mathrm{R}$, Varotto A. Vascular risk factors for primary open angle glaucoma: the Egna-Neumarkt Study. Ophthalmol 2000; 107: 1287-93.

17. Razeghinejad MR, Pro MJ, Katz LJ. Non-steroidal druginduced glaucoma. Eye (London, England) 2011; 25: 971 80.

18. Rudolph JL, Salow MJ, Angelini MC, McGlinchey RE. The anticholinergic risk scale and anticholinergic adverse effects in older persons. Arch Intern Med 2008; 168: 508-13.

19. Garbe E, LeLorier J, Boivin JF, Suissa S. Risk of ocular hypertension or open-angle glaucoma in elderly patients on oral glucocorticoids. Lancet 1997; 350: 979-82.

20. Alm A, Camras CB, Watson PG. Phase III latanopros studies in Scandinavia, the United Kingdom and the United States. Surv Ophthalmol 1997; 41 Suppl 2: S105-10.

21. DuBiner $\mathrm{H}$, Cooke D, Dirks M, Stewart WC, VanDenburgh AM, Felix C. Efficacy and safety of bimatoprost in patients with elevated intraocular pressure: a 30-day comparison with latanoprost. Surv Ophthalmol 2001; 45 Suppl 4: S35360.

22. Miyake $\mathrm{K}$, Ota I, Maekubo $\mathrm{K}$, Ichihashi S, Miyake S. Latanoprost accelerates disruption of the blood-aqueous barrier and the incidence of angiographic cystoid macular edema in early postoperative pseudophakias. Arch Ophthalmol 1999; 117: 34-40.

23. Maenpaa J, Pelkonen O. Cardiac safety of ophthalmic timolol. Expert Opin Drug saf 2016; 15: 1549-61.

24. Nelson WL, Fraunfelder FT, Sills JM, Arrowsmith JB, Kuritsky JN. Adverse respiratory and cardiovascular events attributed to timolol ophthalmic solution, 19781985. Am J Ophthalmol 1986; 102: 606-11.

25. Van Buskirk EM. Adverse reactions from timolol administration. Ophthalmol 1980; 87: 447-50.

26. Freedman SF, Freedman NJ, Shields MB, Lobaugh B, Samsa GP, Keates EU, et al. Effects of ocular carteolol and timolol on plasma high-density lipoprotein cholesterol level. Am J Ophthalmol 1993; 116: 600-11.

27. Velde TM, Kaiser FE. Ophthalmic timolol treatment causing altered hypoglycemic response in a diabetic patient. Arch Intern Med 1983; 143: 1627.

28. Geiss LS, Wang J, Cheng YJ, Thompson TJ, Barker L, Li $Y$, et al. Prevalence and incidence trends for diagnosed diabetes among adults aged 20 to 79 years, United States, 1980-2012. JAMA 2014; 312: 1218-26.

29. Korte JM, Kaila T, Saari KM. Systemic bioavailability and cardiopulmonary effects of $0.5 \%$ timolol eyedrops. Graefes Arch Clin Exp Ophthalmol 2002; 240: 430-5.
30. Nieminen T, Uusitalo $H$, Turjanmaa V, Bjarnhall G, Hedenstrom $\mathrm{H}$, Maenpaa J, et al. Association between low plasma levels of ophthalmic timolol and haemodynamics in glaucoma patients. Eur J Clin Pharmacol 2005; 61: 36974.

31. Edeki TI, He H, Wood AJ. Pharmacogenetic explanation for excessive beta-blockade following timolol eye drops. Potential for oral-ophthalmic drug interaction. JAMA 1995; 274: 1611-3.

32. Maenpaa J, Volotinen-Maja M, Kautiainen H, Neuvonen M, Niemi M, Neuvonen PJ, et al. Paroxetine markedly increases plasma concentrations of ophthalmic timolol; CYP2D6 inhibitors may increase the risk of cardiovascular adverse effects of $0.5 \%$ timolol eye drops. Drug Metabol Disp: Biol Fate Chemicals 2014; 42: 2068-76.

33. Samuelsson O, Zoega H, Gudmundsson A, Halldorsson M. Algengi geðlyfjanotkunar eldri Íslendinga utan stofnana. Læknablaðið 2009; 95: 11-7.

34. Pringle SD, MacEwen CJ. Severe bradycardia due to interaction of timolol eye drops and verapamil. BMJ 1987; 294: 155-6.

35. Salim S, Shields MB. Glaucoma and systemic diseases. Surv Ophthalmol 2010; 55: 64-77.

36. Maren TH, Conroy CW, Wynns GC, Levy NS. Ocular absorption, blood levels, and excretion of dorzolamide, a topically active carbonic anhydrase inhibitor. J Ocul Pharmacol Ther 1997; 13: 23-30.

37. Buclin T, Biollaz J, Lippa EA, Brunner-Ferber F, van Melle $\mathrm{G}$, Munafo A, et al. Absence of metabolic effects of the topical carbonic anhydrase inhibitors MK-927 and sezolamide during two-week ocular administration to normal subjects. Clini Pharmacol Ther 1991; 49: 665-73.

38. Sweeney KR, Chapron DJ, Brandt JL, Gomolin IH, Feig PU, Kramer PA. Toxic interaction between acetazolamide and salicylate: case reports and a pharmacokinetic explanation. Clin Pharmacol Thera 1986; 40: 518-24

39. Kobayashi H, Kobayashi K, Kiryu J, Kondo T. Pilocarpine induces an increase in the anterior chamber angular width in eyes with narrow angles. Brit J Ophthalmol 1999; 83: 553-8.

40. Sirois FJ. Pilocarpine psychosis. Psychosoma 2005; 46: 88

41. Brooks AM, Gillies WE. Ocular beta-blockers in glaucoma management. Clinical pharmacological aspects. Drugs Aging 1992; 2: 208-21.

42. Epstein DL, Grant WM. Carbonic anhydrase inhibitor side effects. Serum chemical analysis. Arch Ophthalmol 1977; 95: 1378-82.

43. Adkins JC, Balfour JA. Brimonidine. A review of its pharmacological properties and clinical potential in the management of open-angle glaucoma and ocular hypertension. Drugs Aging 1998; 12: 225-41. 


\section{Medical management of glaucoma and interaction between glaucoma and systemic medications}

Valgerður Dóra Traustadóttir ${ }^{1}$

Elín Björk Tryggvadóttir ${ }^{2}$

Ólöf Birna Ólafsdóttir ${ }^{1,3}$

Aðalsteinn Guðmundsson ${ }^{3,4}$

María Soffía Gottfreðsdóttir ${ }^{1,3}$

Introduction: Glaucoma used to be the most common cause for blindness in Iceland. As the incidence of glaucoma increases with age, the patients often have numerous comorbidities and use various medications. It is important to keep in mind interactions and side effects of glaucoma medications when deciding systemic medical treatment for these patients to ensure their safety and comfort. The goal of the study was to gather information about drug use of patients with severe glaucoma.

Methods: A retrospective study where data were collected from 100 consecutive patients who underwent a trabeculectomy as first glaucoma surgery at Landspitali National University Hospital of Iceland during 2013-2017. All systemic and ophthalmic medications during 6 months before and after the surgery, medical diagnoses, age and gender of the patients were registered. Results: Of all 100 patients, 87 used systemic medication, averaging 5.3 drugs/patient. Mean number of glaucoma medication used was 3.0. Mean age at surgery was 75 years and 53 were women. The most common systemic drug class was antihypertensives, used by 57 patients where beta-blockers were the most common, used by 30 patients. Zopiclone was the most common single drug, used by 29 patients.

Conclusion: It is evident that patients with glaucoma take various drugs for systemic illness that can affect their glaucoma and have interactions with glaucoma drugs. It is urgent that healthcare providers keep this in mind when deciding on systemic treatment for patients with glaucoma, with regards to possible interactions with glaucoma drugs and the effect on patient's overall health.

${ }^{1}$ Ophthalmology Landspitali University Hospital, ${ }^{2}$ Ophthalmology Lunds Universitet, Sweden, ${ }^{3}$ University of Iceland, Reykjavik, ${ }^{4}$ Geriatrics K4, Landspitali University Hospital.

Key words: Glaucoma, drug interactions, prostaglandin analogues, timolol, beta-blockers, carbonic anhydrase inhibitors, alpha agonists, pilocarpine.

Correspondence: Valgerður Dóra Traustadóttir, valadorat@gmail.com 